Indonesian Journal of Islamic Communication, Vol. 1, No. 2, Desember 2018: 103-122

\title{
REPRESENTASI PEREMPUAN MUSLIMAH DALAM FILM AYAT AYAT CINTA: RESEPSI DAN REINTERPRETASI AKTIVIS MUSLIMAH PKS, FATAYAT DAN NASYIATUL AISYIYAH DI KABUPATEN JEMBER
}

\author{
Nada Hindawiyah \\ Program Studi Komunikasi dan Penyiaran Islam \\ Institut Agama Islam Negeri Jember
}

Diunggah 29 Desember / Direvisi 05 Januari / Diterima 28 Januari 2019

\begin{abstract}
Abstrac: This research departs from media phenomena in constructing reality. The reality displayed by the media is considered as the real truth by the public, even though the facts presented by the media are not a single truth. As is the reality of the understanding of Muslim women in religious films, how do Muslim women activists perceive and reinterpret the Muslim woman figure into an interesting topic to explore, especially the views of PKS Muslim activists, Fatayat and Nasyiatul Aisyiyah in Jember Regency. This study aims to describe how the representation of Muslim women depicted in the Ayat Ayat Cinta film describes how women from PKS, Fatayat and Nasyiatul Aisyiyah represent and reconstruct understanding of the understanding of Muslim women in the Ayat Ayat Cinta movie, and describe the structure of PKS activist thinking, Fatayat and Nasyiatul Aisyiyah in describing the figure of a Muslim woman represented in the Ayat Ayat Cinta film. This research provides results that representations of Muslim women featured in the Ayat Ayat Cinta film have one common character, namely maintaining self-esteem. As for how to dress variously, but in one corridor closes the genitals from the toe to the tip of the head except the face and both palms. In responding and reinterpreting Muslim female figures, PKS Muslim activists, Fatayat, and Nasyiatul Aisyiyah have their own point of view, but broadly the Muslim female figure featured in the Ayat Ayat Cinta film represents the ideal Muslim woman. The structure of thought that underlies PKS Muslim activists, Fatayat and Nasyiatul Aisyiyah in understanding Muslim women is more dominantly influenced by various factors outside the film, such as family, environment and organizational factors.
\end{abstract}

Keywords; Representasi, Resepsi dan Reinterpretasi

Korespondensi: Nada Hindawiyah

Pascasarjana Institut Agama Islam Negeri Jember 


\section{A. PENDAHULUAN}

Perempuan menjadi objek konstruksi berbagai pihak termasuk media massa. Perempuan oleh media massa digambarkan sangat tipikal yaitu tempatnya ada di rumah, berperan sebagai ibu rumah tangga dan pengasuh, tergantung pada pria, tidak mampu membuat keputusan penting, menjalani profesi yang terbatas, selalu melihat pada dirinya sendiri, sebagai obyek seksual, obyek peneguhan pola kerja patriarki, objek pelecehan, kekerasan, selalu disalahkan dan bersikap pasif, serta menjalankan fungsi sebagai pengkonsumsi barang dan jasa sebagai alat pembujuk. ${ }^{1}$

Eksistensi perempuan tidak terwakili secara proporsional di media massa baik media hiburan maupun berita. Melalui penggambaran semacam itu, kaum perempuan mengalami penindasan yang dilakukan jaringan kekuasaan dalam berbagai bentuk, misalnya berupa ketergantungan kepada suami, pembatasan peran sosial sebagai istri dan ibu rumah tangga. ${ }^{2}$ Media menunjukkan kepada khalayak bagaimana penindasan terhadap perempuan digambarkan sebagai sesuatu hal yang wajar dan menjadi bagian dari realitas sosial, dengan membentuk realitas sosial sebagaimana yang dikehendai oleh media.

Dennis McQuail menyebutkan salah satu peran penting media adalah memberikan gambaran realitas sosial.3 Realitas yang dihadirkan media tidak terlepas dari fungsi media sebagai pembangun persepsi, opini dan perilaku masyarakat. 4 Media tidak mampu menghadirkan keseluruhan realitas yang terjadi di masyarakat, akan tetapi media membuat realitas yang mewakili realitas sesungguhnya melalui proses rekonstruksi.

Media merupakan subyek konstruksi realitas yang dilengkapi dengan bias dan pemihakan, oleh karena itu media disebut sebagai agen konstruksi realitas. 5 Hasilnya realitas yang dibangun media memungkinkan meniadakan realitas lain yang ada di masyarakat. Tentu realitas yang ditampilkan dalam tayangan media tidak lepas dari berbagai kepentingan, baik politik, sosial, ekonomi atau paham tertentu. Realitas yang dihadirkan merupakan representasi dari realitas sesungguhnya.

\footnotetext{
${ }^{1}$ Sunarto. Televisi, Kekerasan dan Perempuan. (Jakarta: PT Kompas Media Nusantara. 2009). 4.

2 Ibid., 4.

${ }^{3}$ Nuruddin. Pengantar Komunikasi Mass. (Jakarta: PT. RajaGrafindo Persada. 2007). 34.

4 Iwan Awaludin Yusuf. Media, Kenikmatan dan Identitas Budaya Minoritas. (Yogyakarta: UII Press Yogyakarta, 2005). 7.

5 Ibid., 8.
} 
Konstruksi realitas yang dibangun melalui media dapat ditampilkan melalui film. Film menampilkan nilai-nilai, gambaran dan ideologi yang dibangun seolah-olah merupakan realitas sesungguhnya, Stuart Hall menyebutnya sebagai representasi. 6 Media penyampaian representasi melalui film tidak terlepas dari nilai-nilai yang dihadirkan di dalamnya. Penyampaian nilai-nilai melalui media efektif sebagaimana dalam teori jarum hipodermik tentang seberapa besar efek yang ditimbulkan oleh media massa. Media massa diibaratkan sebagai peluru yang jika ditembakkan tepat, sasaran tidak dapat menghindar, analogi ini menunjukkan bahwa peluru memiliki kekuatan besar dalam mempengaruhi sasarannya. 7

Sebagai contoh film religi menampilkan nilai-nilai ajaran Islam, seolah-olah menggambarkan tolak ukur ideal nilai-nilai ajaran Islam sebagaimana yang digambarkan dalam film, sebagaimana penelitian Asep Supriadi dalam tesisnya. 8 Apa yang ditampilkan dalam film sedikit banyak mempengaruhi khalayak, menjadi sebuah panutan, atau bahkan tuntunan yang dianggap sebagai realitas sesungguhnya yang harus diaplikasikan dan ditiru dalam kehidupan nyata, kemudian disebut sebagai efek media.

Televisi dan Film merupakan salah satu media populer yang cukup aktif dan aktraktif dalam mengkonstruk perempuan untuk berbagai kepentingan. Film-film bernuansa Islami banyak diminati oleh khalayak yang mayoritas beragama Islam, secara tidak langsung kehadiran film bernuansa Islami memberikan pengaruh terhadap khalayak. Masyarakat muslim dituntut mencari acuan makna untuk menjadi muslim yang baik tanpa mempertimbangkan konsekuensi dalam tataran praktis, akibatnya khalayak muslim terjebak dalam konstruksi makna tentang bagaimana menjadi muslim yang baik. 9

Film Ayat Ayat Cinta menampilkan citra perempuan muslimah moderen yang akomodatif terhadap moderenitas sekaligus konsisten menampilkan keimanannya. Film Ayat Ayat Cinta merupakan film yang merepresentasikan pesan-pesan dakwah baik verbal maupun nonverbal salah satunya adalah anjuran untuk menjunjung tinggi

\footnotetext{
${ }^{6}$ Menurut Stuart Hall representasi merupakan hubungan makna dan budaya, representasi berarti menggunakan bahasa untuk menyebutkan sesuatu yang penuh arti kepada orang lain. Ibid., 10.

${ }^{7}$ Nuruddin. Deddy Nur Hayati. Pengantar Komunikasi Massa. (Jakarta: Raja Grafindo Persada. 2007). 215.

${ }^{8}$ Asep Supriyadi. Transformasi Nilai-nilai Ajaran Islam dalam Ayat Ayat Cinta Karya Habiburrahman ElShirazy Kajian Interteks. (Semarang: Tesis Ilmu SusastraUNDIP. 2006).

9 Syiqqil Arafat. Representasi Perempuan dalam Film Bernuansa Islami. (Depok: Jurnal Refleksi Vol. 3 Universitas Indonesia. 2013). 498.
} 
nilai-nilai perempuan.10 Perempuan ditampilkan sebagai sosok muslimah yang memiliki peranan sama besar dengan laki-laki pada satu sisi. Salah satu contohnya perempuan diperbolehkan menuntut ilmu sampai tingkat sarjana dan diperbolehkan mengambil keputusan, disisi lain perempuan juga ditampilkan sebagai sosok yang tertindas seperti teraniaya dan tidak mampu menyampaikan pendapat.11

Film Ayat Ayat Cinta booming dan diproduksi dalam 2 seri pada tahun 2008 dan 2017. Film tersebut merupakan film fenomenal yang mampu menarik jutaan penonton.12 Sebagai pembanding, berikut data rating film religi yang dapat dihimpun dari beberapa artikel sepanjang tahun 2008-2017:

\section{Tabel 1.1}

Rating Film Religi

\begin{tabular}{|l|c|c|}
\hline \multicolumn{1}{|c|}{ Judul Film } & Tahun Tayang & Jumlah Penonton \\
\hline Ayat Ayat Cinta & 2008 & 3,5 juta \\
\hline Ayat Ayat Cinta 2 & 2017 & 2,5 juta \\
\hline Ketika Cinta Bertasbih & 2009 & 2,1 juta \\
\hline Ketika Cinta Bertasbih 2 & 2009 & 1,4 juta \\
\hline $\begin{array}{l}\text { Surga yang Tak } \\
\text { dirindukan }\end{array}$ & 2015 & 1,5 juta \\
\hline $\begin{array}{l}\text { Surga yang Tak } \\
\text { dirindukan 2 }\end{array}$ & 2017 & 1,6 juta \\
\hline 99 Cahaya dilangit Eropa & 2013 & 1,8 juta \\
\hline Hijrah Cinta & 2014 & 700 ribu \\
\hline
\end{tabular}

Sumber data diolah dari berbagai artikel

Tabel menyebutkan tingkat film religi selama beberapa tahun terakhir mempertimbangkan jumlah penonton film yang mencapai jutaan. Rentang waktu 10 tahun antara film Ayat Ayat cinta 1 dan 2 tidak menyurutkan minat khalayak untuk menyaksikan film tersebut, dengan judul yang sama namun dengan alur cerita yang

\footnotetext{
${ }^{10}$ Sri Wahyuningsih. Representasi Pesan-pesan Dakwah dalam Film Ayat Ayat Cinta. (Madura: Jurnal KARSA Fakultas Ilmu Sosial dan Ilmu Budaya Universitas Trunojoyo. 2013)

${ }^{11}$ Sosok perempuan yang ditampilkan dalam film Ayat Ayat Cinta sedikit banyak diadopsi oleh khalayak sebagaimana fungsi media sebagai transmission of values atau penyebaran nilai-nilai yang termasuk dalam fungsi media sebagai sosialization, cara kerjanya mengacu pada bagaimana individu atau khalayak mengadopsi perilaku dan nilai kelompok. Alvinaro Ardianto. Lukiati Nurmala. Siti Karlinah. Komunikasi massa suatu pegantar edisi revisi. (Bandung: Simbiosa Rekatama Media. 2009). 317.

${ }^{12}$ Sri Wahyuningsih. Representasi Pesan-pesan Dakwah dalam Film Ayat Ayat Cinta. 317.
} 
berbeda. Secara garis besar dalam film Ayat Ayat Cinta 1 menceritakan tentang bagaimana mengatasi berbagai persoalan hidup dengan cara Islami,13 sedangkan pada film Ayat Ayat Cinta 2 mengisahkan tentang Islamophobia di Eropa.14

Penelitian tentang film Ayat Ayat Cinta ini banyak dikaji dengan sudut pandang seputar pesan dakwah dan nilai-nilai ajaran agama, sebagaimana penelitian yang dilakukan oleh Sri Wahyuningsih dalam judul "Representasi Pesan-pesan Dakwah dalam Film Ayat Ayat Cinta", sedangkan dari sudut pandang representasi perempuan muslimah merupakan sudut pandang baru yang layak untuk diteliti. Jarang ditemukan kajian yang spesifik membahas bagaimana ideologi dalam film apabila dikaji melalui beberapa pemahaman organisasi, kelompok, aktivis dan paguyuban.

Aktivis muslimah PKS, Fatayat dan Nasyiatul Aisyiyah menjadi kelompok aktivis muslimah yang mewakili keberagaman ormas Islam, dengan ideologi yang berbeda dari sudut pandang pemahaman Islam yang berbeda pula. Aktifis muslimah PKS, Fatayat dan Nasyiatul Aisyiyah menjadi bagian dari khalayak yang ikut terlibat dalam menyaksikan berbagai film-film religi.

Salah satu film religi tersebut adalah film Ayat Ayat Cinta yang mengkonstruksi realitas tentang perempuan muslimah, dalam film tersebut digambarkan seperti apakah idealnya perempuan muslimah sebagaimana yang diperankan oleh tokoh-tokoh perempuan muslimah seperti Aisyah. Konstruksi perempuan muslimah ideal yang ditampilkan dalam film kemudian direkonstruksi kembali oleh khalayaknya, dalam hal ini aktivis muslimah PKS, Fatayat dan Nasyiatul Aisyiyah menjadi bagian dari rekonstruksi ulang sosok perempuan muslimah.

Bagaimana khalayak memaknai perempuan muslimah yang digambarkan dalam film Ayat Ayat Cinta, kemudian di selaraskan dengan realitas pemahaman keagamaan dari aktivis muslimah PKS, Fatayat dan Nasyiatul Aisyiyah. Kehadiran aktivis muslimah PKS, Fatayat dan Nasyiatul Aisyiyah mampu mewakili pemahaman dari aktivis muslimah lainnya. Ketiganya juga merupakan aktivis yang eksis, sehingga penelitian ini dapat dijadikan acuan penelitian serupa.

\section{B. PEMBAHASAN}

\footnotetext{
${ }^{13} \mathrm{https}$ //id.wikipedia.org/wiki/Ayat-Ayat_Cinta_(film) (26 maret 2018)

${ }^{14} \mathrm{http}: / /$ showbiz.liputan6.com/read/3187481/ini-beda-ayat-ayat-cinta-2-dengan-film-pertama.(26 Maret 2018)
} 


\section{Sosok perempuan muslimah yang direpresentasikan oleh film Ayat Ayat Cinta.}

Representsi perempuan muslimah dalam film Ayat Ayat Cinta (2008) dan film Ayata Ayat Cinta (2017) menggambarkan sosok perempuan muslimah yang beragam, melalui tokoh Aisyah sebagai tokoh utama perempuan muslimah dalam film Ayat Ayat Cinta (2008) dan film Ayat Ayat Cinta (2017), ia ditampilkan sebagai sosok perempuan muslimah dengan pakaian yang longgar, berhijab menutup bagian dada, dan bercadar. Karakter yang dibangun sebagai sosok perempuan yang tegas, mampu menjaga diri dan menjaga kehormatannya, taat kepada suami, serta menghargai suami.

Nurul digambarkan sebagai sosok pribadi yang tabah, menjaga harga diri dan kehormatannya dengan cara berpakaian yang tidak jauh berbeda dengan Aisyah, yakni menggunakan baju yang longgar dan menggunakan jilbab yang menutup bagian dada, namun tidak menggunakan cadar.

Nauro tokoh perempuan muslimah lainnya yang ditampilkan dalam film Ayat Ayat Cinta (2008) ini digambarkan sebagai sosok yang yang taat terhadap orangtuanya, pendiam, penakut, tidak berani menyampaikan gagasan, tertindas, lemah, namun ketika memiliki keinginan yang kuat ia merelakan segala cara meski merugikan orang lain, serta berupaya menjaga harga dirinya meski dengan cara yang salah. Secara fisik Nauro menggunakan model pakaian yang cukup sederhana dalam artian menutup aurat secara keseluruhan namun tidak terlalu longgar, dan hijab yang digunakan tidak sampai menutup bagian dada, serta tidak menggunakan cadar.

Tokoh Maria ditampilkan sebagai sosok yang murah hati, pandai menjaga harga diri dan kehormatannya, suka membantu, ramah dan sosok yang ceria. Ketika Maria telah menjadi muslimah, cara berpakaian yang digunakan hampir serupa dengan Nurul dan Aisyah, yakni berpakaian tertutup yang longgar dan mengenakan hijab yang mentup dada, namun tidak menggunakan cadar.

Tokoh lain yang menggambarkan sosok perempuan muslimah dalam film Ayat Ayat Cinta (2017) adalah Hulya, ia ditampilkan sebagai sosok muslimah yang ceria, pandai menjaga kehormatannya, suka menolong, dan mau berusaha. Berbeda dengan tokoh perempuan muslimah lainnya dalam film Ayat Ayat Cinta, 
ia tampil sebagai sosok perempuan muslimah yang lebih modern, artinya dalam berbusana Hulya menggunakan celana ketat, dengan paduan baju yang menutup hingga bagian lutut dan tidak terlalu longgar, ia juga tidak menggunakan hijab pada awalnya, namun belajar menggunakan hijab setelah menikah dengan Fahri.

Dari seluruh tokoh perempuan muslimah yang ditampilkan dalam film Ayat Ayat Cinta, peneliti menemukan satu kesamaan karakter yang menggambarkan representasi perempuan muslimah dalam film tersebut, yaitu perempuan muslimah yang ditampilkan dalam film Ayat Ayat Cinta semuanya memiliki satu karakter yang sama yakni menjaga harga diri. Adapun cara berpakaian yang ditampilkan perempuan muslimah dalam film Ayat Ayat Cinta memiliki berbagai model, dengan acuan yang sama yakni menutup aurat dari ujung kepala hingga ujung kaki, kecuali muka dan telapak tangan.

2. Pandangan aktivis muslimah Fatayat, PKS dan Nasyiatul Aisyiyah meresepsi dan merekonstruksi sosok perempuan muslimah dalam film Ayat Ayat Cinta.

\section{Analisis Film Ayat Ayat Cinta}

a. Analisis Film Ayat Ayat Cinta (2008) dari sudut pandang aktivis muslimah Fatayat.

Secara garis besar dapat disimpulkan bahwa terdapat dua sosok tokoh perempuan muslimah. Pertama ditampilkan dalam tokoh utama perempuan yakni Aisyah, dan kedua adalah Nauro. Kedua Tokoh tersebut memberikan gambaran sosok perempuan muslimah ideal melalui peranan yang ditampilkan dalam adegan-adegan film. Sehingga walaupun terdapat tokoh-tokoh perempuan muslimah lainnya, namun khalayak lebih dominan menilai peranan kedua tokoh tersebut.

Adapun hasil dari resepsi penggambaran sosok Aisyah dalam film Ayat Ayat Cinta seolah sebagai sosok perempuan muslimah ideal. Dapat dilihat dari beberapa sifat dan karakter yang ditampilkan dalam sosok Aisyah, yaitu: dengan ketaatannya dalam beragama meliputi cara berpakaian yang menutup aurat hingga menggunakan cadar, juga kahlak dan perilakunya yang menjaga diri dari pandangan laki-laki, dan tidak bersentuhan dengan laki-laki. Alur cerita dalam film ini adalah alur 
sirkuler, yaitu alur campuran yang merupakan gabungan dari alur maju dan alur mundur.

Nauro sebagai subjek kedua gambaran sosok perempuan muslimah dalam film Ayat Ayat Cinta, memiliki sifat yang bertolak belakang dengan Aisyah. Nauro memiliki sifat penakut dikarenakan perjalanan hidup yang mengerikan, sering mengalami penyiksaan dan penganiayaan dari ayah angkatnya namun ia harus tetap bertahan. Nauro juga digambarkan sebagai sosok perempuan muslimah yang tegar, dan berani berjuang untuk melindungi keluarganya yang dinilai berharga, serta Nauro juga memiliki sifat jujur, meskipun pada awalnya sempat berbohong dan memberikan kesaksian palsu.

Dengan menghadirkan tiga koresponden yakni Ima, Yaya dan Vivi mampu menampilkan pemahaman yang beragam dalam memaknai teks. Sehingga sudut pandang tokoh perempuan muslimah yang ditampilkan dalam film memiliki pemaknaan yang beragam pula.

Analisis atas bagaimana posisi-posisi ditampilkan secara luas akan dapat menyingkap bagaiman ideologi dan kepercayaan dominan bekerja dalam teks. Dalam banyak teks, wanita ditampilkan sebagai objek bukan subjek. Karena sebagai objek representasi, maka wanita posisinya selalu didefinisikan, dijadikan bahan penceritaan, dan ia tidak mampu menampilkan dirinya sendiri. ${ }^{15}$

Sebagaimana dalam film Ayat Ayat Cinta, sosok perempuan muslimah yang ditampilkan melalui tokoh utama Aisyah digambarkan sebagai sosok perempuan muslimah ideal. Penafsiran tersebut sependapat dengan keterangan yang disampaikan Vivi bahwa sosok perempuan muslimah yang digambarkan dalam film Ayat Ayat Cinta sebagai sosok perempuan muslimah ideal, meski pendapat Vivi ini tidak sepaham dengan pendapat yang disampaikan Ima dan Yaya.

Ima menilai sosok perempuan muslimah dalam film Ayat Ayat Cita identik dengan perempuan muslimah yang bercadar. Sedangkan Yaya juga menilai dari sisi penampilan, bagi Yaya perempuan muslimah haruslah

${ }^{15}$ Eriyanto. Analisis Wacana Pengantar Analisis Teks Media. (Yogyakarta: Lkis Grup, 2001). 202. 
yang berpakaian longgar dan sesuai dengan ajaran Islam, yakni menutup aurat kecuali wajah dan telapak tangan.

Sara Mills menjelaskan interpretasi bekerja melalui proses yang kompleks, bagi Mills menggunaan penyaan peyebutan tidak langsung. Menurut Mills penyapaan tidak langsung ini bekerja dengan dua cara, pertama mediasi. ${ }^{16}$ Sebagaimana sosok perempuan muslimah dalam film Ayat Ayat Cinta, dengan pengkisahan tertentu pembaca dapat menempatkan dirinya dalam posisi Aisyah, menyelami sosok perempuan muslimah yang digambarkan dalam sosok Aisyah. Disini pembaca/khalayak tidak disapa secara langsung dengan mengatakan "hai. Lihatlah sosok perempuan muslimah ini!" akan tetapi disapa secara tidak langsung dengan strategi dan cara penceritaan mensugesti kepada khalayak suapaya menempatkan dirinya sebagai sosok perempuan muslimah tersebut. ${ }^{17}$

Kedua, kode budaya istilah yang dikenalkan Roland Barthes mengacu pada kode atau nilai budaya yang dipakai oleh pembaca ketika menafisrkan suatu teks. Menurut Mills kode budaya ini dapat ditemukan dengan mensugestikan sejumlah informasi yang dipercaya dan diakui secara bersama. Kode budaya ini membantu khalayak menempatkan dirinya terutama dengan orientasi nilai yang disetujui dan dianggap benar. ${ }^{18}$

Dari sudut pandang pemahaman teori kosntruksi sosial Peter Berger dan Thomas Luckman, proses resepsi dan reinterpretasi pemahaman tentang sosok perempuan muslimah dalam film Ayat Ayat Cinta melalui tiga tahapan yakni Objektivasi, internalisasi dan eksternalisasi. Ketiga momen dialektika tersebut memunculkan suatu proses konstruksi sosial yang dilihat dari segi asal muasalnya merupakan hasil ciptaan manusia, yaitu buatan interaksi intersubyektif. Melalui proses

\footnotetext{
${ }^{16}$ Mediasi yang dimaksut yakni satu teks umumnya membawa tingkatan wacana dimana posisi kebenaran ditempatkan hirarkis, sehingga pembaca akan mensejajarkan atau mengidentifikasi dirinya sendiri dengan karakter atau apa yang tersaji dalam teks.

${ }^{17}$ Eriyanto. Analisis Wacana. 208.

18 Ibid., 208.
} 
dialektika ini maka realitas sosial pertama dapat dilihat dari ketiga tahap tersebut. ${ }^{19}$

\section{b. Analisis Film Ayat Ayat Cinta dari sudut pandang aktivis muslimah PKS}

Pada bagian ini objek penelitian adalah film Ayat Ayat Cinta (2008) adalah sosok perempuan muslimah yang ditampilkan oleh tokoh Asiyah dan maria.

Aisyah merupakan sosok perempuan muslimah yang mendominasi peranan dalam film, ia diceritakan sebagai seorang muslimah yang menggunakan cadar dengan baju yang tidak menunjukkan lekuk tubuhnya, selalu mengenakan jubah hitam ketika berada diluar rumah. Secara definitif, Aisyah ditampilkan sebagai sosok perempuan muslimah yang memiliki nilai toleransi tinggi, taat beragama, menghormati sesama meski dari agama yang berbeda, serta menjunjung tinggi nilai-nilai kehormatan wanita muslimah.

Maria merupakan subjek kedua yang menggambarkan sosok perempuan muslimah dalam film Ayat Ayat Cinta. Walaupun sosok Maria merupakan perempuan beragama nasrani pada mulanya, namun sikap dan prilakunya sangat kental dengan nilai-nilai ajaran Islam. Maria adalah gadis yang selalu berpakaian sopan, walaupun tidak mengenakan baju lengan panjang, ia adalah sosok yang peduli terhadap sesama dan suka membantu.

Pemahaman tentang sosok perempuan muslimah direpresentasikan oleh sosok Aisyah dan tokoh perempuan muslimah lainnya, menuurt Mills representasi dipahami sebagai bagaimana satu pihak ditampilkan dengan cara tertentu dalam sebuah wacana yang kemudian mempengaruhi pemaknaan ketika diterima oleh khalayak. ${ }^{20}$

Aktivis muslimah PKS sebagai partisipan dalam penelitian ini, menghadirkan tiga koresponden yakni Rina, Nana dan Siti Tini. Dengan kehadiran ketiga koresponden tersebut mampu menampilkan pemahaman yang beragam dalam memaknai teks, sehingga sudut pandang tentang perempuan muslimah memiliki pemahamn yang beragam. Analisis

19 Burhan Bungin. Konstruksi Sosial Media Massa. (Jakarta: Prenada Media Grup, 2008). 15-16.

20 Eriyanto. Analisis Wacana 200. 
terhadap posisi yang ditampilkan secara luas dapat menampilkan idiologi bekerja dalam teks. Sebagaimana sosok perempuan muslimah yang ditampilkan dalam film Ayat Ayat Cinta, perempuan menduduki posisi sebagai objek yang didefinisikan sebagai bahan penceritaan. ${ }^{21}$

Sebagaimana dalam film Ayat Ayat Cinta, Aisyah menduduki sosok perempuan muslimah ideal yang digambarkan sengan karakter baik, santun, bertoleransi, berakhlak dan mampu menjaga harga dirinya. Penjelasan ini sependapat dengan keterangan yang disampaikan oleh ketiga responden dari aktivis muslimah PKS yakni Nana, Siti Tini dan Rina.

Nana berpendapat bahwa sosok perempuan muslimah yang ditampilkan dalam film Ayat Ayat Cinta digambarkan sebagai sosok yang memiliki empati dan kepedulian kepada orang lain, bahkan kepada selain agamanya. Namun disisi lain tokoh Aisyah sebagai tokoh utama pemeran sosok perempuan muslimah, ia memiliki banyak kejangalan karena tidak mampu menjaga harga diri suaminya sehingga menimbulkan permasalahan kemudian. Meski demikian, secara keseluruhan sosok Aisyah bisa dikatakan lumayan jika dinilai dari sudut pandang ideologi koresponden, karena memiliki keberanian untuk mendorong suaminya menikah lagi.

Tini menilai perempuan muslimah sebagai sosok yang memiliki akhlak yang baik dan taat dengan ajaran Islam serta taat beribadah. Dibandingkan dengan memperhatikan gaya hidup dan hal lainnya, kepribadian yang berkaitan dengan hubungan dengan sesama manusia dan hubungan dengan Allah SWT menjadi titik tekan yang lebih penting untuk dinilai, melalui akhlak dan ketaatannya seseorang dinilai sebagai sosok perempuan muslimah yang baik, sebagaimana diperankan oleh tokoh Aisyah.

Rina berpendapat bahwa perempuan muslimah adalah sosok perempuan yang mampu menampilkan dirinya sebagai sosok yang kuat secara mental namun juga baik hatinya. Mampu menjaga kehormatannya

${ }^{21}$ Eriyanto. Analisis Wacana. 202. 
dengan menjaga pergaulannya dengan lawan jenis dan menutup aurat, serta taat kepada suami.

Dilihat dari sudut pandang teori konstruksi sosial Berger dan Luckman, proses resepsi dan reinterpretasi yang dilakukan oleh aktivis muslimah PKS melalui tahapan dialektika yakni objektivasi, internalisasi, dan eksternalisasi. ${ }^{22}$ Objektivasi sebagai tahap awal, aktivis muslimah PKS melakukan pengamatan terhadap film Ayat Ayat Cinta. Dari pengamatan tersebut secara tidak langsung melakukan internalisasi nilai-nilai dan pemahaman tentang sosok perempuan muslimah dalam film Ayat Ayat Cinta, sehingga mampu mengeksternalisasi pemahaman tentang perempuan muslimah.

Pada tahap ketiga yakni proses eksternalisasi, memiliki kesamaan dengan hasil penelitian terhadap aktivis muslimah Fatayat, bahwa dalam melakukan eksternalisasi pemahaman tentang perempuan muslimah dipengaruhi oleh berbagai macam faktor, salah satunya organisasi.

\section{c. Analisis Film Ayat Ayat Cinta dari sudut pandang aktivis muslimah Nasyiatul Aisyiyah}

Sosok perempuan muslimah dalam film Ayat Ayat Cinta (2017) ditampilkan melalui tokoh-tokoh, adapun sosok subjek pertama yang ditampilkan dalam film Ayat Ayat Cinta 2017 adalah Aisyah. Aisyah digambarkan sebagai sosok perempuan muslimah yang secara penampilan sesuai dengan ajaran agama Islam, yakni menutup seluruh tubuh bahka ia mengenakan cadar. Sosok Aisyah juga digambarkan sebagai sosok yang tabah dan rela mengorbankan apapun demi untuk menjaga kehormatannya sebagai perempuan muslimah.

Subjek kedua ditampilkan oleh sosok Hulya. Sosok Hulya ditampilkan sebagai perempuan muslimah yang ceria, menjaga kehormatannya, suka menolong, dan menghargai orang lain. Meski demikian Hulya ditampilkan sebagai sosok yang tidak mengenakan jilbab namun tetap sopan dalam berpakaian, ia adalah sosok muslimah dengan

22 Burhan Bungin. Konstruksi Sosial Media. 15-16. 
penampilan yang sepenuhnya berbeda dengan sosok-sosok perempuan muslimah yang ada dalam film Ayat Ayat Cinta.

\section{Analisis Sosok Perempuan Muslimah dalam Film Ayat Ayat Cinta (2017)} dari Sudut Pandang Aktivis Muslimah Fatayat, PKS dan Nasyiatul Aisyiyah.

\section{a. Perempuan muslimah dalam film Ayat Ayat Cinta menurut pandangan aktivis muslimah Fatayat}

Dalam penyajian data dan analisis ini, peneliti mengungkapkan hasil wawancara yang diperoleh selama masa penelitian. Narasumber dari bab ini adalah aktivis muslimah Fatayat, mereka membeYayan penjelasan dengan santun seperti dibawah ini.

Sosok perempuan muslimah yang direpresentasikan oleh film Ayat Ayat Cinta dalam pandanga aktivis muslimah Fatayat dituturkan sebagai berikut:

Ima berpendapat dalam film Ayat Ayat Cinta sosok perempuan muslimah yang ditampilkan melalui tokoh utama Aisyah menekankan penggunaan cadar. Ima tidak sependapat dengan hal tersebut, baginya menggunakan cadar hukumnya tidak wajib.

Menurut Yaya, sosok perempuan muslimah dalam film Ayat Ayat Cinta tidak hanya menilai satu sisi dari seluruh penampilannya sebagaimana penjelasan yang disampaikan Ima, melainkan menilai seluruh penampilan (cara berpakaian) yang dikenakan secara keseluruhan.

Yaya menilai sosok perempuan muslimah yang ditampilkan dalam film Ayat Ayat Cinta lebih dominan dari sisi cara berpakaian secara keseluruhan. Bagi Yayacara berpakaian yang digambarkan dalam film tersebut cukup merepresentasikan sosok perempuan muslimah ideal. Cara berpakaian yang dimaksut adalah dengan menggunakan baju yang tidak ketat juga kerudung yang tidak ketat dalam artian kerudung yang dikenakan hingga menutup bagian dada. Disisi lain, Yayasependapat dengan Ima yakni menolak menggunakan cadar karena dalam paham NU yang dianutnya, kewajiban menutup aurat seluruh anggota badan kecuali wajah dan telapak tangan. 
Sedangkan menurut Vivi aktivis muslimah Fatayat lainnya menilai sosok perempuan muslimah yang ditampilkan dalam film Ayat Ayat Cinta bukan lagi dinilai dari segi penampilannya saja, melainkan dari sikapnya dalam bergaul sebagaimana dijelaskan berikut:

Berbeda dari penuturan Firti dan Yaya, Vivi lebih menyoroti persoalan sikap. Bagi Vivi sosok perempuan muslimah yang ditampilkan dalam film Ayat Ayat Cinta menggambarkan nilai-nilai ta'aruf, hal yang sudah sangat langka dikalangan remaja dewasa ini. Film tersebut menggambarkan perilaku ta'aruf yang dilakukan oleh Fahri dan Aisyah sebagai tokoh utama, melalui penggambaran tersebut menyampaikan pesan bahwa dalam Islam tidak dikenal pacaran melainkan saling mengenal sebenlum memasuki jenjang pernikahan yang di kenal dengan istilah ta'aruf.

\section{b. Perempuan muslimah dalam film Ayat Ayat Cinta menurut pandangan aktivis muslimah PKS}

Sosok perempuan muslimah yang direpresentasikan oleh film Ayat Ayat Cinta dalam pandangan aktivis PKS disampaikan sebagai berikut:

Nana berpendapat bahwa sosok perempuan muslimah yang ditampilkan dalam film Ayat Ayat Cinta digambarkan sebagai sosok yang memiliki empati dan kepedulian kepada orang lain, bahkan kepada selain agamanya. Namun disisi lain tokoh Aisyah sebagai tokoh utama pemeran sosok perempuan muslimah, ia memiliki banyak kejangalan karena tidak mampu menjaga harga diri suaminya sehingga menimbulkan permasalahan kemudian. Meski demikian, secara keseluruhan sosok Aisyah bisa dikatakan lumayan jika dinilai dari sudut pandang ideologi koresponden, karena memiliki keberanian untuk mendorong suaminya menikah lagi.

Tini berpendapat lain mengenai sosok perempuan muslimah dalam film Ayat Ayat Cinta, ia menilai perempuan muslimah sebagai sosok yang memiliki akhlak yang baik dan taat dengan ajaran Islam serta taat beribadah. Dibandingkan dengan memperhatikan gaya hidup dan hal lainnya, kepribadian yang berkaitan dengan hubungan dengan sesama manusia dan hubungan dengan Allah SWT menjadi titik tekan yang lebih 
penting untuk dinilai, melalui akhlak dan ketaatannya seseorang dinilai sebagai sosok perempuan muslimah yang baik, sebagaimana diperankan oleh tokoh Aisyah.

Menurut Rina, secara prinsp film Ayay Ayat Cinta sudah menampilkan sosok sosok perempuan muslimah yang baik secara umum, dengan penggambaran perempuan yang mempu menjaga kehormatannya, menjaga auratnya serta menjaga hubungan pertemanan laki-laki dengan perempuan. Rina berpendapat bahwa erempuan muslimah adalah sosok perempuan yang mampu menampilkan dirinya sebagai sosok yang kuat secara mental namun juga baik hatinya. Mampu menjaga kehormatannya dengan menjaga pergaulannya dengan lawan jenis dan menutup aurat, serta taat kepada suami.

\section{c. Perempuan muslimah dalam film Ayat Ayat Cinta menurut} pandangan aktivis muslimah Nasyiatul Aisyiyah

Mengenai bagaimana sosok perempuan muslimah yang direpresentasikan oleh Film Ayat Ayat Cinta dalam pandangan aktivis Nasyiatul Aisyiyah disampaikan sebagai berikut:

Dalam Film Ayat Ayat Cinta (2017), sosok perempuan muslimah ditampilkan melalui tokoh Aisyah dan Hulya. Menurut Naiza, Aisyah digambarkan sebagai sosok perempuan muslimah yang sabar dan berani berkorban, sedangkan Hulya digambarkan sebagai sosok yang ceria dan aktif meski tidak mengenakan hijab, namun pada akhirnya ia mau menggunakan hijab atas permintaan suaminya. Hal ini menggambarkan sosok perempuan muslimah dalam film tersebut memilki karakter yang berbeda dalam ketaatannya kepada pRinatah agama, yaitu dalam menerapkan bagaimana mereka berpakaian.

Senada dengan penuturan Naiza, Vina menyebutkan bahwa sosok perempuan muslimah dalam film Ayat Ayat Cinta (2017) adalah Aisyah dan Hulya. Berikut penuturan Vinamengenai bagaimana sosok Aisyah dan Hulya sebagai tokoh perempuan muslimah dalam film:

Vina mengungkapkan bahwa sosok perempuan muslimah dalam film Ayat Ayat Cinta menggambarkan perempuan yang sangat beriman 
untuk menjaga harga dirinya. Begitu pula dengan Hulya, meski ia adalah perempuan muslimah yang tidak mengenakan jilbab Hulya merupakan sosok perempuan yang sopan dengan menunjukkan sikapnya yang senantiasa mengucapkan salam saat bertemu orang lain. Vina menekankan sosok perempuan muslimah berkarakter mampu menjaga kehormatan diri, dengan membatasi pergaulan dengan lawan jenis sehingga tidak menjadikan perempuan tampak hina karena pergaulannya.

\section{Resepsi dan Rekonstruksi Sosok Perempuan Muslimah Menurut Aktivis} Muslimah Fatayat, PKS dan Nasyiatul Aisyiyah dalam Film Ayat Ayat Cinta

a. Resepsi dan merekonstruksi sosok perempuan muslimah menurut aktivis muslimah Fatayat

Ima meresepri sosok perempuan muslimah dalam film Ayat Ayat Cinta sebagai sosok yang baik secara penampilan dan sikap. Sedangkan mereinterpretasikan sosok perempuan muslimah harusnya bersikap toleransi dan memiliki akhlak yang baik. Tidak jauh berbeda dengan penjelasan yang disampaikan Yaya dalam meresepsi dan mereinterpretasi sosok perempuan muslimah dalam film Ayat Ayat Cinta.

Yaya meresepsi dan mereinterpretasi pemahaman tentang sosok perempuan muslimah dalam film Ayat Ayat Cinta sebagai muslimah yang baik, yaitu muslimah yang berbaju tidak ketat dan berkerudung tidak ketat. Yayamereinterpretasi sosok perempuan muslimah sebagai perempuan yang baik secara penampilan dan menutup aurat sebagaimana dalam ajaran NU yakni menutup seluruh tubuh kecuali wajah dan telapak tangan, oleh karenanya Ima tidak setuju dengan penggunaan cadar karena tidak sesuai dengan ajaran NU.

Vivi meresepsi sosok perempuan muslimah yang ditampilkan dalam film Ayat Ayat Cinta sebagai sosok perempuan yang baik secara penampilan fisik dan sikap. Perempuan dalam film tersebut dipahami sebagai sosok perempuan yang menutup aurat dengan baik, juga bersikap baik, memiliki toleransi, juga mnejalankan pRinatah agama. Sedangkan mereinterpretasi sosok perempua muslimah sebagai sosok perempuan muslimah yang menaati perintah agama dan menjauhi larangannya, 
menutup aurat, dan mengaplikasikan ajaran Islam dalam kehidupan sehari-hari.

b. Resepsi dan merekonstruksi sosok perempuan muslimah menurut aktivis muslimah PKS

Dalam meresepsi dan mereinterpretasi sosok perempuan muslimah dalam film Ayat Ayat Cinta menurut aktivis muslimah PKS sebagai berikut: Nana meresepsi sosok perempuan muslimah dalam film Ayat Ayat Cinta sebagai sosok perempuan muslimah yang mampu menjaga diri. Dalam artian bahwa perempuan muslimah tersebut bisa menjaga dirinya ketika bergaul dengan lawan jenis sehingga tidak menjatuhkan harga diri sebagai perempuan muslimah. sedang reinterpretasi sosok perempuan muslimah tidak jauh berbeda, yakni muslimah yang mampu menjaga diri, menutup aurat dengan ketentuan jilbabnya hingga menutup bagian dada.

Pemahaman yang disampaikan Nana berbeda dengan resepsi dan reinterpretasi yang dipahami oleh Siti Tini. Bagi Tini, resepsi sosok perempuan muslimah dalam film memiliki banyak kesamaan dengan reinterpretasi sosok perempuan muslimah bagi dirinya, ia memahami perempuan muslimah sebagai sosok yang taat kepada suami dan berakhlak, bagi Tini hal tersebut sesuai dengan reinterpretasi sosok perempuan muslimah yang ia pahami, yakni sama-sama menjunjung tinggi nilai akhlak.

Berbeda dengan Rina, ia meresepsi dan mereinterpretasi sosok perempuan muslimah dilihat dari karakter atau sifat dan akhlaknya, bagi Rina karakter yang ditampilkan dalam film merupakan sosok perempuan muslimah yang kuat secara mental, dan juga berhati mulia. Namun ia mereinterpretasi sosok perempuan muslimah berbeda dari sekedar penilaian karakter, melainkan dari ketaatannya kepada Allah yang dimanifestasikan dengan ketaatannya kepada suami, menutup aurat, dan menjaga pergaulan terutama dengan lawan jenis.

\section{c. Resepsi dan merekonstruksi sosok perempuan muslimah menurut} aktivis muslimah Nasyiatul Aisyiyah

Dalam meresepsi dan mereinterpretasi sosok perempuan muslimah, aktivis Nasyiatul Aisyiyah menuturkan sebagai berikut: 
Menurut Naiza meresepsi dan mereinterpretasikan sosok perempuan muslimah sebagai berikut: Resepsi dan reinterpretasi yang disampaikan oleh Naiza memiliki kesamaan pemahaman, artinya bahwa Naiza menilai sosok perempuan muslimah yang ditampilkan dalam film sesuai dengan pemahaman dirinya dalam memaknai sosok perempuan muslimah, yaitu bersifat pemberani, tanggung, sabar, ikhlas, berakhlakul karimah dan menutup aurat.

Bagi Vina, perempuan muslimah dalam film menggambarkan sosok perempuan yang mampu menjaga kehormatannya, hal tersebut searah dengan pemahaman reinterpretasi sosok perempuan muslimah yang ia pahami sebagai sosok perempuan yang harus menjaga kehormatan dirinya, serta mengenyam pendidikan setinggi-tingginya. Hal ini dikarenakan perempuan masa kini sudah memilki hak yang sama dengan laki-laki dalam hal memperoleh pendidikan.

\section{Struktur pemikiran yang melandasi aktivis muslimah PKS, Fatayat dan Nasyiatul Aisyiyah dalam memahami sosok perempuan mulimah yang direpresentasikan dalam film Ayat Ayat Cinta.}

Adapun struktur pemikiran yang melandasi aktivis muslimah Fatayat, PKS dan Nasyiatul Aisyiyah dalam memahami sosok perempuan muslimah lebih dominan dipengaruhi oleh berbagai faktor dari luar film tersebut, seperti faktor keluarga, lingkungan dan organisasi.

Hal ini dapat diindikasikan dari hasil wawancara dengan koresponden darimasing-masing aktivis yang ikut serta berpartisipasi memberikan pendapat, yaitu sebagai berikut:

1. Aktivis muslimah Fatayat yang diwakili oleh Ima, Yaya dan Vivi, masingmasing menyampaikan bahwa pengetahuan tentang sosok perempuan muslimah ia peroleh dari organisasi Fatayat, pendidikan dan lingkungan tempat tinggal. ${ }^{23}$

2. Menurut pandangan dari aktivis muslimah PKS yang diwakili oleh nana, Tini dan Rina. Nana berpendapat bahwa pemahaman tentang sosok perempuan muslimah dipengaruhi oleh faktor lingkungan keluarga dan organisasi PKS. ${ }^{24}$

23 Wawancara dilakukan dengan Ima,Yaya dan Vivi aktivis Fatayat. (17 Maret 2018)

24 Wawancara bersama Nana, koresponden dari Aktivis Muslimah PKS. (23 April 2018) 
Sedangkan Tini dan Rina berpendapat dipengaruhi oleh pendidikan, organisasi

PKS dan faktor lingkungan sosial. ${ }^{25}$

Adapun aktivis Nasyiatul Aisyiyah memahami sosok perempuan muslimah diperoleh dari faktor lingkungan sosial, pendidikan dan organisasi Nasyiatul Aisyiyah sebagaimana penuturan Naiza dan Vina. ${ }^{26}$

\section{KESIMPULAN}

Bagi penulis secara pribadi, penelitian ini memberikan pengetahuan tentang berbagai pandangan sosok perempuan muslimah dari sudut pandang aktivis muslimah PKS, Fatayat dan Nasyiatul Aisyiyah, sehingga keberagaman pengetahuan tentang pemaknaan sosok perempuan muslimah tidak hanya terpaku pada satu pemahaman saja, namun pada dasarnya penulis menemukan tali simpul yang menjadi satu kesatuan pemahaman tentang perempuan muslimah dari berbagai sudut pandang aktivis muslimah PKS, Fatayat dan Nasyiatul Aisyiyah, bahwa akhlak merupakan karakter utama yang melekat pada sosok perempuan muslimah.

\section{DAFTAR PUSTAKA}

Arafat, Syiqqil. 2013. Representasi Perempuan dalam Film Bernuansa Islami. Depok: Jurnal Refleksi Vol. 3 Universitas Indonesia.

Ardianto, Alvinaro. Lukiati Nurmala. Siti Karlinah. 2009. Komunikasi massa suatu pegantar edisi revisi. Bandung: Simbiosa Rekatama Media.

Bungin, Burhan. 2008. Konstruksi Sosial Media Massa. Jakarta: Prenada Media Grup. Eriyanto. 2001. Analisis Wacana Pengantar Analisis Teks Media. Yogyakarta: Lkis Grup.

John W. Creswell. Achman Fawaid (Penerjemah). 2010. Research Design Pendekatan Kualitatif,

Kuantitatif, dan Mixed. Yogyakarta: Pustaka Pelajar.

Moloeng, Lexy J.. 2007. Metodologi Penelitian Kualitatif. Bandung: PT Remaja Rosdakarya Offset.

Nuruddin. 2007. Pengantar Komunikasi Mass. Jakarta: PT. RajaGrafindo Persada.

Nuruddin. Deddy Nur Hayati. 2007. Pengantar Komunikasi Massa. Jakarta: Raja Grafindo Persada.

Patilama, Hamid. 2011 Metode Penelitian Kualitatif. Bandung: Alfabeta. 
Rakhmat, Jalaluddin. 1998. Metode Penelitian Komunikasi. Bandung: Remaja Rosdakarya.

Sugiono. 2011. Metode Penelitian Kuantitatif Kualitatif dan R\&D. Bandung: Alfabeta.

Sunarto. 2009. Televisi, Kekerasan dan Perempuan. Jakarta: PT Kompas Media Nusantara.

Supriyadi, Asep. 2006. Transformasi Nilai-nilai Ajaran Islam dalam Ayat Ayat Cinta Karya

Habiburrahman El-Shirazy Kajian Interteks. Semarang: Tesis Ilmu Susastra UNDIP.

Wahyuningsih, Sri. 2013. Representasi Pesan-pesan Dakwah dalam Film Ayat Ayat Cinta. Madura: Jurnal KARSA Fakultas Ilmu Sosial dan Ilmu Budaya Universitas Trunojoyo.

Yusuf, Iwan Awaludin. 2005. Media, Kenikmatan dan Identitas Budaya Minoritas.Yogyakarta: UII Press Yogyakarta.

https://id.wikipedia.org/wiki/Ayat-Ayat_Cinta_(film)

http://showbiz.liputan6.com/read/3187481/ini-beda-ayat-ayat-cinta-2-dengan-filmpertama. 